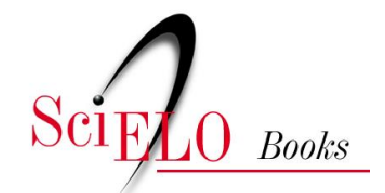

\title{
Overview of Latin American activities in biotechnology
}

\author{
Karl Simpson
}

SIMPSON, K. Overview of Latin American activities in biotechnology. In SORJ, B., CANTLEY, M., and SIMPSON, K., eds. Biotechnology in Europe and Latin America: prospects for co-operation [online]. Rio de Janeiro: Centro Edelstein de Pesquisas Sociais, 2010. pp. 129-135. ISBN: 978-857582-036-6. Available from SciELO Books $<\underline{\text { http://books.scielo.org }>\text {. }}$

\section{(1) $@(0$}

All the contents of this chapter, except where otherwise noted, is licensed under a Creative Commons Attribution-Non Commercial-ShareAlike 3.0 Unported.

Todo o conteúdo deste capítulo, exceto quando houver ressalva, é publicado sob a licença Creative Commons Atribuição Uso Não Comercial - Partilha nos Mesmos Termos 3.0 Não adaptada.

Todo el contenido de este capítulo, excepto donde se indique lo contrario, está bajo licencia de la licencia Creative Commons Reconocimento-NoComercial-CompartirIgual 3.0 Unported. 


\subsection{OVERVIEW OF LATIN AMERICAN ACTIVITIES IN BIOTECHNOLOGY}

Karl Simpson

It has been too easy for Europeans to dismiss Latin America as being a collection of underprivileged third world states. It is true that debt continues to be a pressing problem for almost all of Latin America's economies, but in 1988 Brazil and Mexico seem to be regaining the confidence of the world's financial centres. Argentina's recent re-entry into democracy is a further cause for optimism and in Chile (ignored in SOBELA) there is growing hope of a democratic conclusion to Pinochet's regime.

Each of the Latin American states, but most notably, Argentina, Brazil, Mexico and Venezuela, has a substantial business class, enjoying access to European standards of education, health and consumer commodities. Industrial output, while largely low-tech, has increasingly focused upon new technologies emerging from the R\&D based cultures of the USA, Japan and Europe.

In several areas of biotechnology a number of Latin American nationals have made substantial contributions. Cesar Milstein (Argentinean citizen) gained his Nobel Prize for work on hybridomas. It cannot be overlooked that in the event of substantial improvement in living and working conditions, Latin America may be able to call upon the skills of many technically qualified expatriates working in centres of excellence throughout the world. Both Argentina and Brazil have traditions of excellence in basic research and have a number of long established and internationally recognised laboratories.

In 1984 the United States Office of Technology Assessment, OTA, suggested that the Latin American market for biotechnology would be exploited by the USA and Japan. Europe, they reasoned would not be able to establish a presence. By 1988 it has become clear that Europe has moved and is now establishing a strong position in Latin America, although Japan's involvement is very strong. Paradoxically it is the USA that has failed to capitalise upon its proximity to Latin American markets. This has been aggravated by a hostile reaction to Latin America's generally 'Laissez Faire' approach to intellectual property protection.

A growing sense of community is emerging in Latin America and this is manifest by an increasing number of joint activities in areas of strategic interest such as biotechnology. The states of the Andean Pact have effectively devolved national responsibility to the supra national responsibility of the Pact. Professional Associations such as Brazil's ABRABI (Associação Brasileira de Empresas de Biotecnologias) are spreading throughout the region.

A sense of realism prevails in most of the states. It is realised that commitment to biotechnology is not immediately going to force a dominant position in world markets. It seems more likely that the short term advantages of developments will be a reduction in foreign imports, such as AIDS diagnostic kits or insulin. In the long term it is possible that relatively cheap labour costs and a well educated professional class might permit the exploitation of world markets on an equal footing with companies in Europe, the USA and Japan.

One of the consequences of SOBELA may well be the establishment of joint ventures that realise these hopes in the short term.

In the following lines we paint a very brief picture of biotechnology in the states presented at the SOBELA meeting.

\section{Argentina}

The election of a civil government in 1984 gave impetus to the National Biotechnology Programme, PNB, launched in 1982. Nobe Laureate, Dr Luis Federico Leloir, heads the Executive Committee of the PNB. With major support from the National Department of Science and Technology and the National Council for Scientific and Technical Research, as well as significant input from other ministries, the PNB is orientated towards servicing the needs of industry. Human health and livestock health and improvement have been defined as priorities for the PNB. In the period 1984-86 US\$1.6 million was divided between 90 projects in 70 centres. From a European point of view such expenditure would seem to be spread very thinly. 
Training is a key issue in the Programme and grants are made available for scientists to train in foreign countries. The EEC has been asked for financial support in this area. The PNB is orientated towards international collaboration and links with several countries in Europe exist already (Belgium, France, Federal Republic of Germany, Italy and Sweden). Internal cooperation and particularly the cementation of strong industry/university links are essential if the Programme is to meet its goals. Individual entrepreneurs are expected to take the initiative in establishing such finks, while the PNB will support the activities of a representative body, the Argentine Forum of Biotechnology. Launched in 1986 its President, Dr Aldo Ferrer is also President of the Bank of the Province of Buenos Aires.

A fiscal package has been agreed which accords credit certificates to a value of $60 \%$ of the cost of approved projects. This is also available to foreign entrepreneurs investing in Argentina.

Argentina has developed particularly dose links with Brazil, manifest in the foundation of a joint centre for biotechnology. On this background of activities there is an increase in interest and investment in industrial biotechnology.

\section{Brazil}

With an academic tradition in the biological sciences dating back to the mid 19th century Brazil has a commanding lead over its neighbours. São Paulo, active from the beginning has become the focus for institutes operating in the areas of vaccines, immunology etc. Successful public health campaigns are making progress in the control of typhus, leishmaniasis and other diseases. Agrobiotechnology has achieved some notable successes, using very traditional technologies. Brazil has established commercially valuable Maize hybrids.

There is a strong commercial base for exploiting innovation in biotechnology. Agroceres, the seeds company, was founded in the 1940s. In the 1960s Brasilsul and Agropecuária were founded. These companies can trace their evolution to the work of plant geneticist, Cruz Martins in the 1920s. Other distinguished Brazilian geneticists include Dr Theodosious Dobzhansky.
Companies with an interest in biotechnology have guaranteed Brazil self sufficiency in insulin production, and are looking closely at the local manufacture of products including the interferons. Arable and stock farming is served by many universities and institutes, several of which now boast competence in gene manipulation. Selection of soya cultivars has resulted in an $80 \%$ increase in nitrogen use efficiency in the last 20 years. Genargen has established germ plasm banks, which will help offer protection from North American, Japanese and European companies hoping to exploit Brazil's vast phytochemical resources.

Biotechnology in Brazil cannot ignore the Proalcohol Programme, although this is coming under increasing internal criticism. The programme did much to stimulate local biotechnology related industry and incited contacts with companies such as Denmark's Novo, who became interested in the prospects of selling starch converting enzymes. Perhaps the long-term benefit of the programme will have been the accumulation of know-how in all aspects of the sugar complex.

Although the Ministry of Science and Technology accepts responsibility for control and co-ordination of Brazilian biotechnology, the government, as in Argentina, looks to entrepreneurs to provide the industrial impetus to the programme. More so than anywhere in Latin America industrialists have come forward to launch companies in areas ranging from micropropagation of plants to AIDS diagnostics.

Examples of companies include: Biobras, interested in the manufacture of genetically engineered insulin. Bio-Planta in association with Native Plants have set up an agrobiotechnology research centre. Cibran, the antibiotics company is implementing rDNA technology in its R\&D facility. Embrapa is a public sector company which has a commitment to the exploitation of Brazil's germ plasm resources.

In the public sector the Oswald Cruz Foundation and the Butantã Institute make a major contribution towards biotechnology R\&D. Many of the new companies will participate in the formation of regional poles of biotechnology, where private/public sector integration will be a feature. This activity mirrors what is going on in France.

In Brazil there is a growing concern that biotechnology may threaten the future of employment in the agricultural industry. Increased 
productivity may seriously damage the organisation of society in areas removed from major cities.

\section{Mexico}

Although Mexico has a number of university departments with competence in several aspects of biological science it is true to say that industrial exploitation of biotechnology is dominated by first generation technology. Such technology is manifest in the production of beers and spirits. Second generation technology is used for the production of antibiotics, amino acids and aspartame sweeteners, but all of this technology has been imported from foreign countries.

Several small scale industrial enterprises have been launched to capitalise upon the market for the products of this technology. Enzymology, based in Monterrey, is a company manufacturing aspartame, phenylacetic acid and related chemicals. Bioenzimas, in Saltillo, Coahuila, is an agrobiotechnology company with interests in improved grain yields, insecticides, giberellic acid and agricultural enzymes.

Modern biotechnological innovations such as micropropagation are being initiated by a small number of firms including: Industrial biogenetics, involved in the micropropagation of strawberries, asparagus and violets; Genin, who are working on immobilised enzyme bioreactors and the Forestal Center of Genetics, dedicated to genetic improvement of forests by micropropagation.

Gene manipulation and hybridoma technology are found only in government funded laboratories and universities. In these centres biochemistry and related sciences have been established since the 1930s. Biochemical engineering degrees are awarded by more than 20 institutions, with 7 centres offering postgraduate training.

\section{The Andean Pact}

\section{Bolivia, Columbia, Ecuador, Peru and Venezuela}

The Andean Pact is a structure similar to the EEC. Most of the member states do not have the resources required to fund major programmes in high technology. Under the auspices of the Pact central facilities and concertation measures optimise those skills and technologies available. An Andean Biotechnology Programme has existed since 1986. Within the members of the pact there is considerable variation in wealth and scientific competence. The Andean Council for Science and Technology has principal responsibility for concertation of biotechnology actions within the Andean Pact.

Bolivia is not advanced, but does have a programme focusing on Embryo transfer between species of South American Camelidae. Work is carried out in the Instituto de Genetica Humana, where a programme on the molecular biology of diarrhoea is also active. In 1985 Peru and Bolivia launched the Andean Mining/Metallurgical Programme, PMMA. One aspect of this titled, biohydrometallurgy, concentrates upon the extraction of metals by microbial leaching.

Columbia has a very ambitious National Biotechnology Programme, but given the present level of trained personnel and appropriate facilities it is difficult to see how the programme can be implemented in its present form.

Ecuador has indulged in some limited biotechnological work since 1983, but a realistic government cannot contemplate a significant National Programme. Training is singled out as the most important requirement in the National Plan for biotechnology. Government laboratories are carrying out R\&D in aquaculture, in collaboration with commercial interests. Inexa SA is a small company carrying out meristem culture in collaboration with university laboratories. Pronatec SA is studying the commercial exploitation of natural extracts. Life SA in collaboration with the Instituto Nacional de Higiene is manufacturing vaccines for animals. Levapan is developing fermentation technology. There is hope that it may be possible to stimulate the pharmaceuticals industry by applying rDNA technology and other aspects of modern biotechnology.

Peru has little infrastructure capable of supporting advanced applications of biotechnology. It is the mining industry which has turned to bacterial leaching as a possible tool for the extraction of metal from unworkable deposits. The government sector has some activities in plant biotechnology. A joint programme with Bolivia, supported by the Federal Republic of Germany expands upon national competence in microbial leaching.

Until recently Venezuela has had the privilege of having the highest per capita earnings in Latin America. Decline in oil revenues is forcing a re- 
evaluation of national goals. Biotechnology is seen as a tool with considerable potential and a programme launched in 1984 concentrates on three major areas: Agriculture, Medicine and Industry. In Agriculture the focus of effort is upon the production of pathogen free plants through somatic hybridisation and tissue culture. The potato and yucca plants are the targets for exploitation. Medical priorities include assault upon regional diseases and the development of competence in monoclonal and polyclonal antibody production to back up a domestic competence in diagnostics targeted at cancer, AIDS and epidemiology. rDNA technology is on the agenda for developing gene probes and therapeutic agents. 